\title{
Use and control of heat flows in ventilation shafts of subways with Thermal Power Generation
}

\author{
Anna Barch ${ }^{1, *}$, Sergey Naumenko ${ }^{1}$, Alexandr Kotelnikov ${ }^{1}$, and Lev Muginshtein ${ }^{1}$ \\ ${ }^{1}$ JSC "VNIIZhT" (Railway Research Institute), Moscow, 129626, Russia
}

\begin{abstract}
The variants of schematic technical solution of the system of using secondary energy resources - the waste heat of the subway - for the heating of subway stations are proposed, the results of the feasibility study of the heating of the "Nagatinskaya" station of the Moscow Metro with the use of heat pumps are presented.
\end{abstract}

\section{Introduction}

All developed metro systems of the world without exception are the largest sources of secondary energy resources (SER), which can and should be used both for the heating of the subway stations and for the heating of nearby urban facilities. [1]

In foreign countries, the projects for the use of SER of subways are paid a lot of attention. According to RBC daily agency and other electronic resources, for example, the company Paris Habitat, which provides residents of the French capital with municipal services, since 2011, heats 17 apartments in an apartment building located above the subway station due to the excess heat released: by moving electric trains, power transformers, passenger traffic, etc. In the Stockholm metro, similar heat generation allows heating water, which is then used to heat a 13-storey office building, etc.

The key to using SER of subway is the inclusion of the heat pumps (hereinafter referred to as "HP") in the heating circuit of the production premises of the station.

HPs are one of the most promising and developing areas of alternative energy. This environmentally friendly power plant is capable of transforming heat from a low-temperature source, to which the heat of SER belongs, to a high-temperature one. The most common method is based on the phase transformation of a liquid into a gas, and vice versa. At the first phase transition, heat is removed, at the second one -rejected.

\section{Materials and methods}

The system for the use of SER - waste heat of the subway - (hereinafter - the System), presented in the form of a schematic technical solution, is shown in Fig. 1. [2]

\footnotetext{
* Corresponding author: barch.anna@vniizht.ru
} 


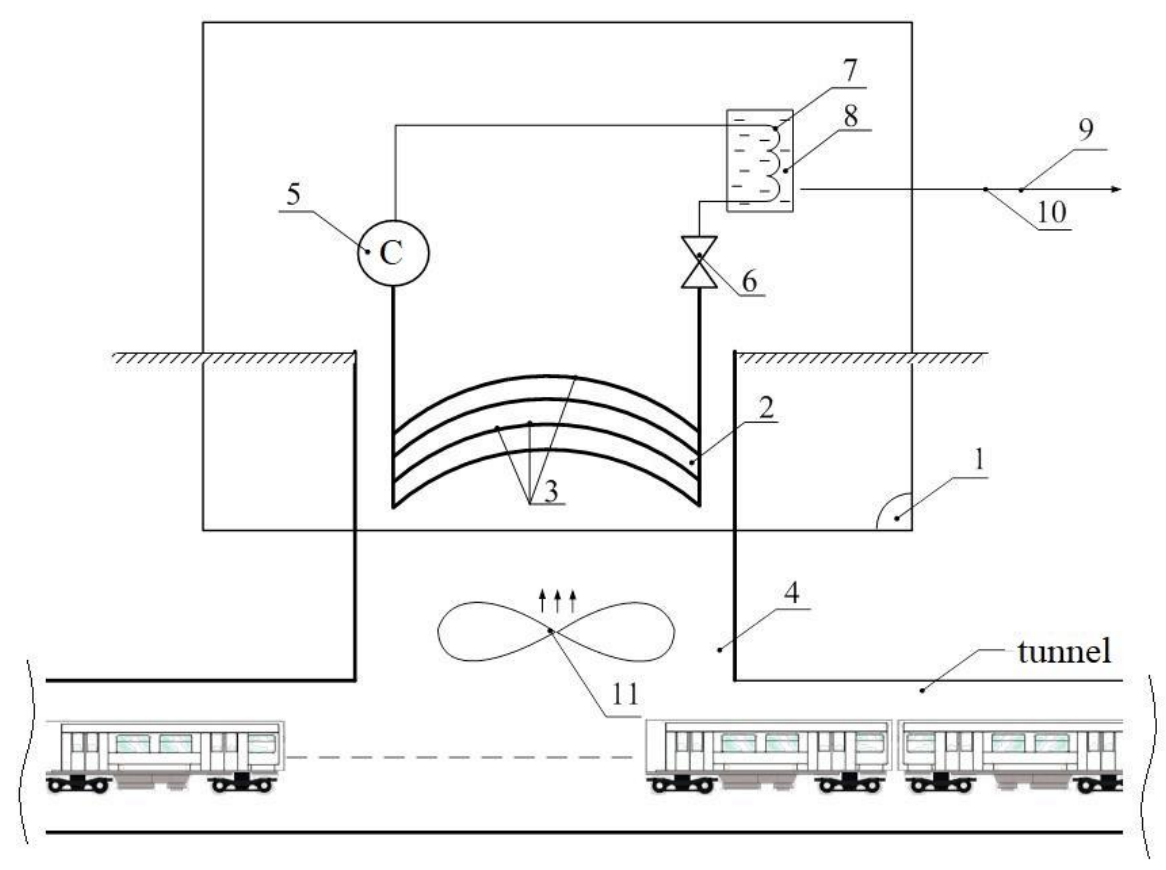

Fig. 1. Schematic technical solution for the use of waste heat of subway, where: 1 - heat pump (HP); 2 - evaporator of HP; 3 - heat exchange surface of HP; 4 - exhaust shaft; 5 - compressor of HP; 6 throttle valve, 7 - condenser of HP; 8 - heat storage tank with water circuit; 9 - system of heating and hot water supply of buildings; 10 - system of heating and hot water supply for the subway's own needs; 11 - fan.

As can be seen from Fig. 1, the System comprised of a heat pump 1 with an evaporator 2 , the heat exchange surface 3 of which is located in a shaft 4 of the subway. Evaporator 2 by means of compressor 5 , throttle valve 6 , condenser 7 , and heat storage tank with water circuit 8 is connected to heating and hot water supply systems of buildings for the use of received hot water in heating and hot water supply systems of buildings 9 on commercial basis and/or for own needs of the subway 10 .

The presented System works as follows. As the air flow generated by the fan 11 passes through the heat exchange surface 3 of the evaporator 2, air transfers its heat to the working fluid circulating in it along the reversible contour, which, due to the heat obtained, begins to boil inside the heat exchange surface and form the steam. The steam is supplied to the working space of the compressor 5 , where it is compressed to a temperature of $80-130^{\circ} \mathrm{C}$ and then sent to the condenser 7 to return the heat obtained through the heat exchange surface of the condenser 7 to the water in the heat storage tank with water circuit 8 . The heated water in the tank of water circuit enters the system of hot water supply of buildings, where, through the use of known heat engineering devices, it is brought to the normative parameters. After that it is sent to the heating and hot water supply systems of buildings 9 on the commercial basis or, directly after the tank, is transferred to similar subway systems for own needs 10 . At the same time, the working fluid in the HP circuit is cooled, transforming into a liquid in the condenser 7, and through the throttle valve 6 reducing the pressure in the system and converting the working fluid into a vapor-liquid mixture is sent back to the evaporator 2 , after which the process is repeated.

This schematic technical solution is characterized by the use of ventilation air removed from the tunnels and vestibules of the subway by the fan 11 with the possibility of maintaining the nominal parameters of the exhaust shaft, depending on its depth. 
Here, the heat exchange surface of the HP evaporator can be located in several most appropriate ways: along the height of the exhaust shaft, transversely, or in combination, consisting of, for example, two parts, one of which will be located along the height of the exhaust shaft, and the second - along its cross section.

In any case, the general rule for the location of the evaporator in the exhaust shaft should be the fact that its heat exchange surface will be made and placed in it with the possibility of maintaining the nominal operating parameters of the exhaust shaft (the estimated volume of air removed from the shaft, the design capacity of the exhaust shaft), depending on its depth. Violation of the specified parameter will lead to malfunctions in the work of the subway.

Table 1 shows the results of the thermal calculation of the area of the heat exchange surface of the HP evaporator depending on the chosen version of its location in the exhaust shaft of the subway with the selected power of compressor and the average values of the overall dimensions inherent to the exhaust shafts.

Table 1. Dimensions of the heat exchange surface of the evaporator depending on the version of its location in the exhaust shaft.

\begin{tabular}{|c|c|c|c|c|}
\hline \multirow{2}{*}{$\begin{array}{l}\text { No } \\
\mathrm{n} / \mathrm{n}\end{array}$} & \multirow[t]{2}{*}{ Calculated parameters } & \multicolumn{3}{|c|}{$\begin{array}{l}\text { Position of the HP evaporator relative to } \\
\text { the shaft's surface }\end{array}$} \\
\hline & & Along & Transversely & Combined \\
\hline 1 & Heating capacity, kW & \multicolumn{3}{|c|}{400,0} \\
\hline 2 & Transformation ratio of HP & \multicolumn{3}{|c|}{3,7} \\
\hline 3 & Power of compressor, kW & \multicolumn{3}{|c|}{108,0} \\
\hline 4 & $\begin{array}{l}\text { Dimensions of the exhaust shaft: } \\
\text { - diameter, } \mathrm{m} \\
\text { - area, } \mathrm{m}^{2} \\
\text { - depth, } \mathrm{m}\end{array}$ & \multicolumn{3}{|c|}{$\begin{array}{c}2,5 \\
4,9 \\
20,0\end{array}$} \\
\hline 5 & Area of condenser, $\mathrm{m}^{2}$ & \multicolumn{3}{|c|}{200,0} \\
\hline 6 & Volume of heated water, $1 / \mathrm{h}$ & \multicolumn{3}{|c|}{3000,0} \\
\hline 7 & Temperature of heated water, ${ }^{\circ} \mathrm{C}$ & \multicolumn{3}{|c|}{65} \\
\hline 8 & Evaporator surface, $\mathrm{m}^{2}$ & 3200,0 & 1800,0 & $2500,0 *$ \\
\hline
\end{tabular}

* - 1500,0 $\mathrm{m}^{2}$ - transverse surface and 1000,0 $\mathrm{m}^{2}$ - surface located along the shaft.

As the calculation results showed, the volume of water heated to $65^{\circ} \mathrm{C}$ in the amount of $3000 \mathrm{l} / \mathrm{h}$ allows it to be used in heating and hot water supply systems of buildings on a commercial basis and/or for the subway's own needs with an effective location of the HP evaporator surface.

\section{Results}

In 2012, a project of feasibility study of the possibility and reasonability of replacing the existing heat supply scheme of the Moscow Metro station "Nagatinskaya" from the boiler house of LLC "Laundry 7" (OOO "Prachechnaya 7") with the scheme of heat supply from the HP.

The station "Nagatinskaya" is located on the Serpukhov radius of the Moscow Metro and does not have the opportunity to connect to the city heating networks. The station is supplied with heat from the boiler house of LLC ""Laundry 7" (former commercial laundry № 7 of "Moscow laundry" trust). The heat energy is supplied to the heat point located in the service room of vestibule № 2 (south exit), and from the boiler room of the heat point is distributed to all consumers of the station. The heat supply of vestibule № 1 (northern exit) is carried out by pipelines laid under the platform of the station.

The main consumers of thermal energy are four air heat curtains $(2$ in each of the vestibules) $-60.45 \%$ of the heat load in winter period. Further, on the basis of the calculated 
load, following parameters are obtained: hot water supply system (HWS) - 21.41\%, ventilation of the utility rooms $-11.05 \%$, and heating of service rooms and ticket halls $7.09 \%$. The total calculated heat consumption is $0.794 \mathrm{Gcal} / \mathrm{h}$ in winter and $0.17 \mathrm{Gcal} / \mathrm{h}$ in summer.

Under the contract for the heat supply from the boiler house of LLC "Laundry 7" and accounts for 2011-12, the cost of the supplied heat energy was determined according to calculated design loads without adjustments for months of heating or summer period.

An inspection of the existing heat supply system of the station and consumers of thermal energy, as well as the study of the working documentation, made it possible to draw the following main conclusion: in view of the complexity of carrying out a serious reconstruction of the heating and ventilation system of the station, one should focus on the application of "air-water" HP, i.e. using thermal energy of the environment and partially vented emissions of the station and supplying water heated to $60{ }^{\circ} \mathrm{C}$ in the existing heat supply system of the station.

In order to eliminate the costs for "heating up" of water during the heating period, it was suggested to reconstruct the air heat curtain, namely: to replace outdated KVB-10 air heaters with air heaters of the VNV series with larger heat exchange surfaces. The lack of heat energy for heating of ticket halls and service rooms was supposed to be compensated by installing electric air heaters or fan heaters.

As an option for heating using the HP, the option of using two HPs was substantiated one for each vestibule.

The results of calculation of the feasibility of the project of heat pump heating at Nagatinskaya station are presented in Table 2.

Table 2. The results of calculation of the feasibility of heat pump heating.

\begin{tabular}{|l|l|c|}
\hline No & \multicolumn{1}{|c|}{ Parameter name } & Value \\
\hline 1 & Total heat generation of HP during the heating period, Gcal/year & 2108,3 \\
\hline 2 & $\begin{array}{l}\text { Electric power consumption for work of HP, } \mathrm{kW} \times \mathrm{h} / \mathrm{year} \\
76246,0\end{array}$ & 60379,0 \\
\hline 3 & $\begin{array}{l}\text { Additional electric power consumption for electric heating, } \\
\mathrm{kW} \times \mathrm{h} / \text { year }\end{array}$ & 280981,0 \\
\hline 4 & $\begin{array}{l}\text { Electric power consumption for HWS in summer period, } \\
\mathrm{kW} \times \mathrm{h} / \text { year }\end{array}$ & 1107586,0 \\
\hline 5 & $\begin{array}{l}\text { Total power consumption with the installation of a HP, } \\
\mathrm{kW} \times \mathrm{h} / \text { year }\end{array}$ & 3411,4 \\
\hline 6 & $\begin{array}{l}\text { Total costs for electric power in monetary terms as of 2012, } \\
\text { thousand rubles/year }\end{array}$ & 3787,9 \\
\hline 7 & $\begin{array}{l}\text { Operating costs with the implementation of HP as of 2012, } \\
\text { thousand rubles/year }\end{array}$ & 10154,4 \\
\hline 8 & $\begin{array}{l}\text { Costs for heat supply from the boiler house of LLC “Laundry 7", } \\
\text { thousand rubles/year }\end{array}$ & 6363,5 \\
\hline 9 & Decrease in total costs, thousand rubles/year & 3,9 \\
\hline 10 & Simple payback period, years & \multicolumn{1}{|c|}{} \\
\hline
\end{tabular}

\section{Discussion}

Since 2013, HPs have been successfully used in shafts of the Minsk Metro. The source of low-potential thermal energy is air from the transport tunnel. HPs operate only in the heating period. The coefficient of performance of HP was 3.0. By now, 22 HPs with a total capacity of $403 \mathrm{~kW}$ have been installed in the Minsk Metro [3]. The project continues to develop. 
In addition, a pilot project was implemented in the Moscow Metro in 2017 [4]. It is noted in the conclusions of experts that the Moscow Metro emits into the environment about 2.2 billion $\mathrm{kW} \cdot \mathrm{h}$ of low-potential heat energy per year. Technologies that use heat pumps already allow the recycling of this secondary heat and using it for energy-efficient heating of nearby buildings and structures, trade pavilions, apartment houses, heating of sidewalks and squares in front of stations, etc. Approximate calculations show that only by connecting third-party consumers of heat to such heat supply systems, the Moscow Metro (according to the tariffs of PJSC "MOEK" (Moscow United Energy Company) for connection of heat load) could receive an income exceeding 4 billion rubles aside from the annual income from the sale of thermal energy.

Thus, the use of heat pumps in the exhaust shafts of the subway predicts the obtaining of a significant potential that can be used for the heat supply of the stations. [5-7]

The results of the calculation made it possible to formulate the following conclusions:

\section{Conclusions}

The conducted survey and the performed calculations prove the possibility of transferring the existing heat supply scheme of the "Nagatinskaya" station of the Moscow Metro to the heat pump heating.

The main disadvantage of the decision under consideration is a sufficiently high initial investment. This indicator is a characteristic and main limiting factor for all areas of alternative energy, including for HP.

The positive characteristics of heat pump heating of the station include:

1. a sharp (2.7 times!) reduction in operating costs for the heat supply of the station;

2. elimination of the dependence of heat energy supply on a third-party source - boiler house of LLC "Laundry 7";

3. a relatively short (less than 4 years) payback period for initial investment, which, after an instrumental express inspection, is likely to decrease, as well as primary costs;

4. a long service life of the main installed equipment (up to 30 years), which saves more than 190 million rubles for the life cycle of the product (in prices for 2012) and repeatedly recoup the initial investment.

Subways are significant sources of low-potential heat, which must be used for the heat supply of buildings by means of heat pumps.

\section{References}

1. O.L. Danilov, A.V. Klimenko, Energy saving in heat power engineering and heat technologies (Publishing house of Moscow Power Engineering Institute, Moscow, 2010)

2. A.B. Kosarev, S.N. Naumenko, N.M. Kostin, Waste heat recovery system of subway: pat. on the PM № 120753 Russian Federation: IPC: F24F 12/00 (2006.01) F24D 15/04 (2006.01) (2012)

3. Heat pumps produced by "Geothermatex", http://telemiks.by/geo/enterprise.html

4. G.P. Vasiliev, Ventilation, heating, air conditioning, heat supply, and construction thermal physics 2, 14 -26 (2018)

5. B.N. Minaev, Infrastructure and rolling stock of the subway, proceedings of International exhibition-conference "Intermetro-2017”, MIIT, 96 - 97 (2017)

6. S.N. Naumenko, Vestnik VNIIZhTa 77-4, 200-204 doi.jrg/10.21780/2223-9731-2018-77-4-200-204 